\title{
AKTIVITAS ANTIBAKTERI EKSTRAK TEMPE TERHADAP BAKTERI Bacillus subtilis DAN Staphylococcus aureus
}

\author{
[Antibacterial Activity of Tempe Extracts on Bacillus subtilis and Staphylococcus aureus]
}

\author{
D. Elysa Putri Mambang ${ }^{1)^{*}}$, Rosidah ${ }^{1)}$ dan Dwi Suryanto ${ }^{21}$ \\ 1) Program Studi Magister Farmasi Fakultas Farmasi, Universitas Sumatera Utara, Medan \\ 2) Departemen Biologi Fakultas Matematika dan IImu Pengetahuan Alam, Universitas Sumatera Utara, Medan
}

Diterima 13 Agustus 2013 / Disetujui 05 Februari 2014

\begin{abstract}
Tempe is a soybean fermented product by Rhizopus oligosporus which contains high amounts of bioactive compounds including antibacterial compounds. The aim of this research is to observe the antibacterial activity of tempe extract against Bacillus subtilis and Staphylococcus aureus. The results of this research broadens the current knowledge of tempe as functional food. Samples of commercial tempe were obtained from a traditional market of Pringgan Medan, Sumatera Utara. Tempe samples were then extracted using three solvents with different polarity: ethanol, $n$ hexane and ethyl acetate, each at three levels of concentration i.e. $300 \mathrm{mg} / \mathrm{mL}(30 \%), 400 \mathrm{mg} / \mathrm{mL}$ (40\%) and $500 \mathrm{mg} / \mathrm{mL}$ (50\%). The antibacterial activity test of tempe extracts was carried out using disc difussion method on Mueller Hinton Agar (MHA), and incubation was conducted at 36$37^{\circ} \mathrm{C}$ for 24 hrs. The obtained data were tested statistically with Analysis of Variant (ANOVA) $p>0.05$. The ethanol and ethyl acetate extracts of tempe inhibited the growth of B. subtilis and S. aureus. Meanwhile, the ethyl acetate extract of tempe at concentration of $500 \mathrm{mg} / \mathrm{mL}$ had the highest inhibition against $S$. aureus as shown by inhibition diameters of $15.50 \pm 0.44 \mathrm{~mm}$ ( $p>0.05)$, and B. subtilis at $14.13 \pm 0.21 \mathrm{~mm}(p>0.05)$. No inhibition observed with the $n$-hexane extracts of tempe against the above bacteria.
\end{abstract}

Keywords: antibacterial activity, Bacillus subtilis, Staphylococcus aureus, tempe extract

\section{ABSTRAK}

Tempe adalah produk fermentasi kedelai oleh kapang Rhisopus oligosporus yang mengandung komponen bioaktif dalam jumlah tinggi termasuk di dalamnya komponen antibakteri. Penelitian ini bertujuan untuk mengetahui aktivitas antibakteri tempe terhadap bakteri Bacillus subtilis dan Staphylococcus aureus. Hasil penelitian ini bermanfaat untuk pengembangan tempe sebagai makanan fungsional. Tempe yang digunakan dalam penelitian ini adalah tempe komersial yang diperoleh dari pasar tradisional Pringgan, Medan, Sumatera Utara. Proses ekstraksi tempe dilakukan dengan menggunakan 3 jenis pelarut yang berbeda kepolarannya yaitu etanol, etil asetat dan $n$-heksana dengan tingkat konsentrasi yang berbeda yaitu $300 \mathrm{mg} / \mathrm{mL}(30 \%), 400 \mathrm{mg} / \mathrm{mL}(40 \%)$ dan $500 \mathrm{mg} / \mathrm{mL}$ (50\%). Pengujian aktivitas antibakteri dilakukan dengan metode difusi menggunakan kertas cakram pada media Mueller Hinton Agar (MHA), dan inkubasi dilakukan pada suhu $36-37^{\circ} \mathrm{C}$ selama 24 jam. Data yang diperoleh diuji secara statistik menggunakan metode Analisa Varian (ANOVA) $p>0.05$. Hasil penelitian menunjukkan bahwa ekstrak etanol tempe dan ekstrak etil as etat tempe memiliki daya hambat terhadap pertumbuhan bakteri Gram positf $B$. subtilis dan $S$. aureus. Ekstrak etil asetat tempe $500 \mathrm{mg} / \mathrm{mL}$ memiliki daya hambat paling besar terhadap $S$. aureus yaitu sebesar $15.50 \pm 0.44 \mathrm{~mm}(p>0.05)$ dan $B$. subtilis sebesar $14.13 \pm 0.21 \mathrm{~mm}$ $(p>0.05)$. Ekstrak $n$-heksana tempe tidak memiliki daya hambat terhadap bakteri tersebut.

Kata kunci: aktivitas antibakteri, Bacillus subtilis, ekstrak tempe, Staphylococcus aureus

\section{PENDAHULUAN}

Tempe kedelai adalah produk fermentasi dari kacang kedelai yang berasal dari Indonesia. Mikroba yang berperan dalam pembuatan tempe merupakan kultur campuran yang kompleks, yaitu kapang, kamir, bakteri asam laktat dan beberapa jenis bakteri lainnya. Rhizophus merupakan kapang yang paling berperan dalam pembuatan tempe (Nout dan Kiers, 2005).

Proses fermentasi kedelai menyebabkan terjadinya perubahan sifat fungsional akibat dari proses hidrolisis yang meliputi hidrolisis protein menjadi asam amino dan peptida oleh

*Penulis Korespondensi:

Email: ely saputri_mambang@yahoo.co.id enzim proteolitik; hidrolisis oligo sakarida menjadi monosakarida; serta degradasi asam fitat menjadi pospat anorganik (Pablo et al. 2010). Perubahan ini menjadikan tempe kedelai memiliki nilai gizi yang tinggi karena jumlah protein terlarut dari kedelai akan meningkat menjadi empat kali lipat (Bintari et al. 2008), mengubah flavor langu kedelai menjadi flavor tempe yang disukai, memiliki senyawa bioaktif untuk kesehatan (Nakajima et al. 2005); serta terdapat kemungkinan menurunkan zat anti gizi seperti asam fitat dan polifenol (Cueves-Rodriquez et al. 2004).

Kapang Rhizopus memproduksi antibiotik yang melawan beberapa mikroba penyebab penyakit (Roubus-van den Hil et al. 2010a). Orang Indonesia yang mengonsumsi tempe secara terus-menerus akan terhindar dari disentri dan gangguan pencernaan (Babu et al. 2009). Kasus diare pada anak babi yang diberi diet tempe lebih rendah daripada anak babi yang 
diberi biji kedelai yang dipanggang (Kiers et al. 2003). Efek ant diare tempe ini berhubungan dengan karakteristik antibakterinya. Penelitian tentang antibakteri dari tempe sudah banyak dilakukan, yaitu terhadap Bacillus subtilis, Escherichia coli, Lactobacillus acidophilus dan Lactoacillus paracasei (Kuligowski et al. 2013), Bacillus cereus (Roubus-van den Hil et al. 2009; Roubus-van den Hil et al. 2010a).

Isolasi komponen bioaktif dapat dilakukan melalui proses ekstraksi menggunakan pelarut dan jenis pelarut yang digunakan tergantung pada sifat alami dan kelarutan dari komponen yang akan diekstraksi (Sultana et al. 2009). Pelarut, metode ekstraksi dan konsentrasi pelarut merupakan faktor ekstrinsik yang penting dalam menentukan sifat antibakteri yang diekstraksi dari suatu bahan (Thomas et al. 2012). Pelarut organik seperti etanol, aseton, dan metanol sering digunakan untuk mengekstraksi komponen bioaktif, tetapi etanol merupakan pelarut yang paling banyak digunakan oleh industri obat-obatan herbal karena produk akhir yang diperoleh aman digunakan untuk pengobatan internal (Low, 2009). Berdasarkan hal tersebut maka perlu dilakukan penelitian terhadap aktivitas antibakteri tempe menggunakan pelarut organik sehingga diperoleh senyawa sesuai dengan sifat kepolarannya yang memberikan efek optimum dalam menghambat pertumbuhan bakteri Gram positif.

Penelitian ini bertujuan untuk mengetahui jenis dan konsentrasi larutan pengekstrak terhadap kemampuan antimikroba tempe yang diuji pada Bacillus subtilis dan Staphylococcus aureus.

\section{BAHAN DAN METODE}

\section{Bahan}

Bahan penelitian yang digunakan ialah tempe yang diambil dari Pasar Tradisional Pringgan, Medan, Sumatera Utara. Bakteri uji berupa Bacillus subtilis ATCC 6633 dan Staphylococcus aureus ATCC 29737 diperoleh dari Laboratorium Mikrobiologi Fakultas Farmasi USU.

\section{Pembuatan ekstrak tempe (Saraswaty et al. 2002)}

Pembuatan ekstrak tempe dilakukan dengan cara mememarkan $300 \mathrm{~g}$ tempe dengan lumpang. Kemudian bahan dimaserasi di dalam wadah kaca berwarna gelap masingmasing dengan pelarut etanol (E-Merck) 96\%, n-heksana (EMerck) dan efil asetat (E-Merck) sampai seluruh tempe terendam, ditutup dan disimpan pada suhu kamar $\left(27 \pm 2^{\circ} \mathrm{C}\right)$ selama 5 hari, sambil sesekali diaduk. Kemudian larutan tersebut disaring sehingga didapat maserat Maserat didiamkan selama 2 hari untuk menguapkan sisa pelarut, lalu filtrat dipekatkan dengan bantuan alat rotary evaporator (Buchi 461) pada suhu tidak lebih dari $50^{\circ} \mathrm{C}$ sampai diperoleh ekstrak kental, kemudian dikeringkan dengan freeze dryer (Modulio). Masing-masing ekstrak etanol (E-Merck), n-heksana (E-Merck) dan etil asetat (E-Merck) tempe ditimbang sebanyak $5 \mathrm{~g}$ menggunakan neraca analitik (Vibra AJ) kemudian dilarutkan dalam dimetilsulfoksida (E-Merck) sampai larut dan dicukupkan dengan etanol (E-Merck) pada labu ukur $10 \mathrm{~mL}$ sehingga diperoleh konsentrasi $500 \mathrm{mg} / \mathrm{L}$ selanju tnya dibuat pengenceran dengan konsentrasi 400 dan $300 \mathrm{mg} / \mathrm{mL}$.

\section{Pembuatan suspensi bakteri uji (NCCLS, 2003)}

Bakteri yang digunakan ialah bakteri Gram positif (Bacillus subtilis ATCC 6633 dan Staphylococcus aureus ATCC 29737). Stok kultur dibuat dengan cara menumbuhkan masing-masing bakteri uji pada media NA (Oxoid) miring dengan cara menggores, kemudian diinkubasi dalam inkubator (Fischer Scientific) pada suhu $36-37^{\circ} \mathrm{C}$ selama $18-24$ jam. Koloni bakteri diambil dari stok kultur dengan jarum ose steril lalu disuspensikan dalam tabung reaksi yang berisi $10 \mathrm{~mL}$ larutan Nutrient Broth (Oxoid), sambil diukur kekeruhannya pada panjang gelombang $580 \mathrm{~nm}$ dengan spektrofotometer visibel (Dynamica), sampai diperoleh transmitan 25\% (konsentrasi bakteri $1.0 \times 10^{6} \mathrm{CFU} / \mathrm{mL}$ ).

\section{Pengujian antibakteri (NCCLS, 2003)}

Pengujian antibakteri dilakukan terhadap ekstrak etanol (EMerck), ekstrak n-heksana (E-Merck), ekstrak etil asetat (EMerck) dengan metode difusi agar menggunakan kertas cakram (Oxoid). Inokulum bakteri diambil sebanyak $0.1 \mathrm{~mL}$ menggunakan pipet mikro (Eppendorf) dicampur homogen dengan 15 mL Mueller Hinton Agar (MHA) (Oxoid) di cawan petri steril, kemudian dibiarkan sampai media memadat. Pada media yang telah padat diletakkan kertas cakram (oxoid) yang sudah berisi masing-masing ekstrak berbagai konsentrasi, dan untuk pembanding kontrol positif dipakai kertas cakram yang sudah berisi antibiotik amoksisilin $30 \mu \mathrm{g} / \mathrm{mL}$ (Oxoid). Kemudian diinkubasi di dalam inkubator pada suhu $36-37^{\circ} \mathrm{C}$ selama $18-24$ jam. Selanjutnya diameter daerah bening di sekitar kertas cakram diukur menggunakan jangka sorong. Ekstrak yang diuji dibuat dalam 3 ulangan, dan pengujian masing-masing ekstrak dilakukan dengan duplo.

\section{Analisis data (Steel dan Torrie, 1993)}

Analisis data dilakukan dengan statistik non parametrik menggunakan program komputer SPSS versi 14. Data diameter hambat dari masing-masing bahan uji dianalisis dengan menggunakan uji Kolmogorov-Smirnov untuk melihat apakah data terdistribusi normal atau tidak normal. Selanjutnya uji dilanjutkan dengan menggunakan uji Homogeneity of Varian untuk mengetahui apakah varian dari data homogen atau tidak homogen. Jika data yang diperoleh terdistribusi tidak normal, dilakukan analisis menggunakan uji Kruskal-Wallis yang dilanjutkan dengan uji beda rata-rata Mann-Whitney.

\section{HASIL DAN PEMBAHASAN}

\section{Daya antibakteri ekstrak etanol, etil asetat dan n-heksana tempe terhadap Bacillus Subtilis dan Staphylococcus aureus}

Tabel 1 menunjukkan hasil pengujian antibakteri ekstrak etanol, efil asetat dan n-heksana tempe terhadap bakteri Gram positif $B$. Subtilis dan $S$. aureus. Penghambatan bakteri Gram positif $B$. Subtilis dan $S$. aureus oleh ekstrak etanol dan etil asetat terjadi pada ekstrak dengan konsentrasi 50, 40, dan $30 \%$, sedangkan ekstrak n-heksana tempe tidak memiliki daya hambat terhadap kedua bakteri yang diuji. Uji normalitas dengan uji Kolmogorov-Smirnov menunjukkan adanya 
perbedaan yang nyata $(p<0.05)$ pada diameter hambat ekstrak dengan pelarut yang berbeda. Diameter hambat ekstrak etil asetat, etanol dan n-heksana tempe terhadap Bacillus subtilis homogen dengan nilai signifikansi 0.083 . Diameter hambat ekstrak etil asetat, etanol dan n-heksana tempe terhadap Staphylococcus aureus tidak homogen, sehingga tidak memenuhi kriteria parametrik, oleh sebab itu digunakan uji Kruskal-Wallis yang menunjukkan nilai signifikansi sebesar $0.001(p<0.05$, taraf kepercayaan $95 \%)$, berarti terdapat perbedaan antar kelompok bahan uji.

Tabel 1. Diameter hambat ekstrak etil asetat, etanol dan n-heksana terhadap B. subtilis dan S. aureus

\begin{tabular}{lcc}
\hline \multirow{2}{*}{ Perlakuan } & \multicolumn{2}{c}{ Diameter Hambat $(\mathrm{mm}) \pm$ SDa) } \\
\cline { 2 - 3 } & \multicolumn{1}{c}{ B. subtilis } & S. aureus \\
\hline EEAT $500 \mathrm{mg} / \mathrm{mL}$ & $14.13 \pm 0.21^{\mathrm{a}}$ & $15.50 \pm 0.44^{\mathrm{a}}$ \\
EEAT $400 \mathrm{mg} / \mathrm{mL}$ & $12.10 \pm 0.30^{\mathrm{b}}$ & $14.87 \pm 0.21^{\mathrm{a}}$ \\
EEAT $300 \mathrm{mg} / \mathrm{mL}$ & $11.43 \pm 0.15^{\mathrm{c}}$ & $13.27 \pm 0.25^{\mathrm{a}}$ \\
EET $500 \mathrm{mg} / \mathrm{mL}$ & $9.93 \pm 0.15^{\mathrm{d}}$ & $10.87 \pm 0.35^{\mathrm{a}}$ \\
EET $400 \mathrm{mg} / \mathrm{mL}$ & $8.83 \pm 0.15^{\mathrm{e}}$ & $9.30 \pm 0.20^{\mathrm{a}}$ \\
EET $300 \mathrm{mg} / \mathrm{mL}$ & $8.27 \pm 0.15^{\mathrm{f}}$ & $8.27 \pm 0.25^{\mathrm{a}}$ \\
En-HT $500 \mathrm{mg} / \mathrm{mL}$ & $6^{\mathrm{g}}$ & $6^{\mathrm{b}}$ \\
En-HT $400 \mathrm{mg} / \mathrm{mL}$ & $6^{\mathrm{a}}$ & $6^{\mathrm{b}}$ \\
En-HT $300 \mathrm{mg} / \mathrm{mL}$ & $6^{\mathrm{g}}$ & $6^{\mathrm{b}}$ \\
Kontrol $(-)$ & $6^{\mathrm{g}}$ & $6^{\mathrm{b}}$ \\
Amoksisillin $0.030 \mathrm{mg} / \mathrm{mL}$ & $12.03 \pm 0.06^{\mathrm{b}}$ & $11.45 \pm 0.09^{\mathrm{a}}$
\end{tabular}

Keterangan: a) SD = Standar Deviasi; EEAT = Ekstrak etil asetat tempe, EET = ekstrak etanol tempe, En-HT = ekstrak n-heksana tempe b)Diameter kertas 6 $\mathrm{mm}{ }^{c}$ ) Angka yang dikuti dengan huruf y ang sama pada kolom y ang sama berbeda tidak nyata pada taraf kepercayaan $95 \%(p>0.05)$ dengan uji Kruskal-Wallis

Komponen bioaktif tempe dengan aktivitas antibakteri terbentuk selama fermentasi kedelai (Roubus-van den Hil dan Nout, 2011). Hasil penelitian Bintari, et al. (2008) menunjukkan selama fermentasi tempe oleh Rhizopus sp. dihasilkan zat antibakteri berupa glikoprotein, sehingga pertumbuhan bakteri Gram positif Micrococcus luteus yang merupakan salah satu kontaminan pada tempe terhambat. Senyawa glikoprote in (Bintari et al. 2008), golongan protein (amina) yang telah diisolasi dari media yang diinokulasikan biakan $R$. oligosporus (Saraswaty et al. 2002) dan senyawa flavonoid (isoflavon) merupakan beberapa senyawa golongan antimikroba yang terdapat pada tempe.

Tabel 1 menunjukkan daya hambat yang diberikan oleh ekstrak efil asetat pada konsentrasi 30, 40, dan 50\% terhadap $B$. subtilis dan $S$. aureus lebih besar dari daya hambat amoksisilin $0.030 \mathrm{mg} / \mathrm{mL}$. Daya hambat ekstrak tempe baik ekstrak etil asetat maupun ekstrak etanol terhadap bakteri $B$. subtilis lebih rendah daripada daya hambatnya terhadap bakteri S.aureus, sebaliknya daya hambat amoksisilin terhadap $B$. subtilis lebih besar daripada daya hambatnya terhadap $S$. aureus. Daya hambat ekstrak etil asetat tempe terhadap $S$. aureus cenderung lebih tinggi daripada daya hambat amoksisilin, meskipun secara statistik berbeda tidak nyata kecuali pada konsentrasi ekstrak $50 \%$. Daya hambat ekstrak etanol tempe terhadap $B$. subtilis dan $S$. aureus lebih rendah daripada daya hambat amoksisilin. Hasil ini menunjukkan bahwa $S$. aureus cenderung memiliki resistensi yang lebih tinggi terhadap antbakteri daripada B. subtilis. Adanya sifat kepolaran yang hampir sama dari golongan senyawa kimia yang terkandung di dalam ekstrak etil asetat terhadap sifat lapisan membran luar bakteri Gram positf menyebabkan ekstrak etil asetat lebih mudah masuk ke dalam membran dinding sel bakteri Gram positif, sehingga efek antibakteri ekstrak etil ase tat lebih besar daripada ekstrak etanol.

Bakteri Gram positf memiliki kandungan peptidoglikan yang tinggi dan lipid yang lebih rendah dibandingkan bakteri Gram negatif (Pratiwi, 2008), hal ini menyebabkan Gram positif menjadi lebih bersifat polar. Etil ase tat memiliki kepolaran yang lebih rendah daripada etanol. Ekstraksi yang dilakukan dengan maserasi menggunakan pelarut etanol akan menarik senyawa yang bersifat polar, sedang ekstraksi dengan maserasi menggunakan pelarut etil asetat menarik senyawa yang bersifat semipolar dan dan senyawa dengan tingkat kepolaran yang rendah. Hasil ini juga menunjukkan bahwa ekstrak efil asetat memiliki kepolaran yang hampir sama dengan lapisan luar dinding sel bakteri Gram positif sehingga daya hambatnya lebih besar daripada ekstrak etanol. Bakteri Gram positif seperti $B$. subtilis dan $S$. aureus memiliki struktur dinding sel yang berlapis, sedangkan bakteri Gram negatif mempunyai satu lapis yang tebal. Salah satu mekanisme antibiotik ialah merusak struktur dinding sel pada membran plasma sehingga kemampuan membran plasma sel bakteri sebagai penghalang (barrier) osmosis menjadi berkurang dan mengganggu sejumlah proses biosintesis yang diperlukan dalam me mbran (Brogden, 2005).

Tabel 1 juga menunjukkan bahwa aktivitas antibakteri dari ekstrak tempe baik dengan menggunakan pelarut etil asetat, etanol, maupun $\mathrm{n}$-heksana hampir sama pada kisaran konsentrasi $300-500 \mathrm{mg} / \mathrm{ml}$. Aktivitas antibakteri yang hampir sama pada kisaran konsentrasi terendah dan tertinggi menunjukkan bahwa pengaruh berat molekul dan laju difusi melalui media agar lebih besar daripada konsentrasi ekstrak tempe. Diameter hambat yang besar berhubungan dengan berat molekul yang rendah dan laju difusi dari komponen antibakteri yang cepat pada media agar (Thomas et al. 2012). Pada proses fermentasi tempe, beberapa strain dari kapang Rhizopus mendegradasi makromolekul yang menghasilkan komponen bioaktif (Roubus van den Hill et al. 2010b). Penelitian Roubus et al. (2010a) menunjukkan komponen antibakteri dari $R$. oligosporus pada substrat tempe kedelai adalah berupa molekul peptida dengan berat molekul $<3 \mathrm{kDa}$.

Tabel 1 menunjukkan ekstrak n-heksana tidak memiliki daya hambat terhadap bakteri Gram positif (B. subtilis dan $S$. aureus). n-heksana merupakan pelarut bersifat non polar sehingga menarik senyawa non polar dalam jumlah lebih besar dari pada yang terdapat dalam ekstrak etanol dan etil asetat. Bakteri Gram positif memiliki lapisan membran luar (outer wall layer) yang terdiri dari lapisan peptidoglikan dan bersifat polar. Perbedaan kepolaran antara senyawa kimia yang ditar ik pelarut n-heksana dengan dinding sel bakteri Gram positif (B. subtilis dan $S$. aureus), menyebabkan ekstrak n-heksana tempe tidak dapat mempengaruhi permeabilitas membran sel bakteri gram positif yang bersifat polar. 


\section{KESIMPULAN}

Ekstrak etanol dan etil asetat tempe bersifat antibakteri terhadap bakteri Gram positif Bacillus subtilis dan Staphylococcus aureus pada konsentrasi 500, 400, dan 300 $\mathrm{mg} / \mathrm{mL}$. Ekstrak etil asetat tempe $500 \mathrm{mg} / \mathrm{mL}$ memiliki daya hambat paling besar terhadap $S$. aureus sebesar $15.50 \pm 0.44$ $\mathrm{mm}(p>0.05)$ dan $B$. subtilis sebesar $14.13 \pm 0.21 \mathrm{~mm}(p>0.05)$. Ekstrak $n$-heksana tempe tidak memiliki daya hambat terhadap bakteri $B$. subtilis dan $S$. aureus.

\section{DAFTAR PUSTAKA}

Babu PD, Bhakyaraj R, Vidhyalakshmi R. 2009. A low cost nutritious "Tempe" - A Review. World J Dairy Food Sci 4: 22-27.

Bintari SH, Anisa DP, Veronika EJ, Rivana CR. 2008. Efek inokulasi bakteri Micrococcus luteus terhadap pertumbuhan jamur benang dan kandungan isoflavon pada proses pengolahan tempe. Biosaintifika 1:1-8.

Brogden KA. 2005. Antimicrobial peptides: Pore formers or metabolic inhibitors in bacteria?. Nat Rev Microbiol 3: 238250. DOI: $10.1038 /$ nrmicro1098.

Cuevas-Rodriguez EO, Milan-Carrilli J, Mora-Escobedo R, Cardenas-Valenzuela OG, Reyes-Moreno C. 2004. Quality protein maize (Zea mays $\mathrm{L}$ ) tempe flour through solid state fermentation process. LWT-Food Sci Technol 37: 54-67. DOI: 10.1016/S0023-6438(03)0013.

Kiers JL, Nout MJR, Rombouts FM, Nabuurs MJA, van der Meulen J. 2003. Effect of fermented soya beans on diarrhoea and feed efficiency in weaned piglets. J Appl Microbiol 95: 545-552. DOI: 10.1046/j.1365-2672.2003. 02011.x.

Kuligowski M, Jasinska-Kuligowska I, Nowak J. 2013. Evaluation of bean and soy tempe influence on intestinal bacteria and estimation of antibacterial properties of bean tempe. Pol J Microbiol 62: 189-194.

Low DT. 2009. Smart talk on supplements and botanicals. Alternative Complementary Therapies 15: 101-102. DOI: 10.1089/act2009.15106.

Nakajima N, Nozaki N, Ishihara K, Ishikawa A, Tsuji H. 2005. Analysis of isoflavone content in tempe, a fermented soybean and preparation of a new isoflavone-enriched tempe. J Biosci Bioeng 100: 685-687. DOI: 10.1263/jbb. 100.685 .
[NCCLS] National Committee for Clinical Laboratory Standards. 2003. Performance Standards for Antimicrobial Disk Susceptibility Tests. $6^{\text {th }}$ Ed M2-M8, Wayne, PA.

Nout MJR, Kiers JL. 2005. Tempe fermentation, innovation and functionality: update into the third millennium. J Appl Microbiol 98: 789-805. DOI: 10.1111/j.1365-2672.2004. 02471.x.

Pablo DR, Gabriela TP, Maria CA, Alberto EL. 2010. Optimization of additive combination for improved soy-wheat bread quality. Food Bioprocess Techl 3: 395-405. DOl: 10.1007/s11947-008-0080-z.

Pratiwi ST. 2008. Mikrobiologi Farmasi. Jakarta: Erlangga.

Roubos-van den HPJ, Nout MJR. 2011. Anti-Diarrhoeal a spects of fermented soya beans, soybean and health. El-Shemy $\mathrm{H}$ (Ed.), ISBN: 978-953-307-535-8, In Tech. DOI: 10.5772/ 17997.

Roubus-van den HPJ, Dalmas E, Nout MJR, Abee T. 2010a. Soya bean tempe extracts show antibacterial activity against Bacillus cereus cells and spores. J Appl Microbiol 109: 137145. DOI: 10.1111/j.1365-2672.2009.04637.x.

Roubos-van den HPJ, Nout MJR, van der Meulen J, Gruppen H. $2010^{\text {b }}$. Bioactivity of tempe by inhibiting adhesion of ETEC to intestinal cells, as influenced by fermentation and starter pure cultures. Food Microbiol 27: 638-644. DOI: 10.1016/ j.fm.2010.02.008.

Roubus-van den Hil PJ, Nout MJR, Beumer RR, van der Meulen J, Zwietering JH. 2009. Fermented soya bean (tempe) extracts reduce adhesion of enterotoxigenic Escherichia coli to intestinal epithelial cells. J App Microbiol 106: 1013-1021. DOI: 10.1111/j.1365-2672.2008.04068.x.

Saraswaty V, Zainal A, Dewi R. 2002. Uji Aktivitas Antibakteri dari Medium Sabouraud Cair yang diperkaya dengan Infus Kacang Kedelai dan telah Diinokulasikan dengan Jamur Tempe Rhizopus sp. Prosiding Seminar Tantangan Penelitian Kimia. Hal. 67-74.

Steel RGD, Torrie JH. 1993. Prinsip dan Prosedur Statistika: Suatu Pendekatan Biometrik. Gramedia Pustaka Utama, Jakarta. p.633-648.

Sultana B, Anwar F, Ashraf M. 2009. Effect of extraction solventtechnique on the antioxidant activity of selected medicinal plant extracts. Molecules 14: 2167-2180. DOI: 10.3390/molecules14062167.

Thomas BT, Effedua HI, Agu GC, Akinduti PA, Ejilude O, Efuntoye MO, Ayodele AE, Oluwadun A. 2012. Extrinsic factors influencing antibacterial activities of Tapinanthus bangwensis against diarrheal causing organisms. Int $\mathrm{J}$ Microbiol Res 3: 33-37. DOI: 10.5829/idosi.ijmr.2012.3.1. 56210. 